\title{
Thyroid Gland Mucosa-Associated Lymphoid Tissue Lymphoma
}

National Cancer Institute

\section{Source}

National Cancer Institute. Thyroid Gland Mucosa-Associated Lymphoid Tissue

Lymphoma. NCl Thesaurus. Code C7601.

An extranodal marginal zone B-cell lymphoma arising from mucosa-associated lymphoid tissue in the thyroid gland. The vast majority of cases are associated with chronic lymphocytic thyroiditis. 